УДК 636.2.082.355.083

(C) 2017

Борщ О. О., кандидат сільськогосподарських наук

Білоцерківський НАУ

Рубан С. Ю., доктор сільськогосподарських наук, професор, член-кореспондент НААН НУБіП України

\title{
ІНТЕНСИВНІСТЬ ВИРОЩУВАННЯ КРОСБРЕДНИХ ТЕЛИЦЬ ЗА РІЗНИХ ТЕХНОЛОГІЙ УТРИМАННЯ
}

\begin{abstract}
Використання кросбридингу, як елемента поліпшення молочної худоби у комерційних стадах вплинуло на ріст $i$ розвиток телиць першого покоління у порівнянні з чистопородними аналогами. Телиці української чорно-рябої молочної породи характеризувалися більи високими показниками живої маси порівняно з швіцькими помісями, тоді як телиці отримані в результаті схрещування монбельярдської породи з украӥнською червоно-рябою молочною породою, навпаки відзначались більшою живою масою, порівняно з червоно-рябими аналогами. За індексами, що характеризують інтенсивність їх росту та розвитку телиці украӥнської чорно-рябої молочної породи мали вищі показники порівняно з помісними аналогами. В дослідженнях проведених на помісних телицях української червоно-рябої молочної та монбельярдської породах встановлено, щз вони за показниками характеру росту переважали червоно-рябих аналогів.
\end{abstract}

Ключові слова: кросбридинг, жива маса, прирости, швидкість росту, технологї утримання.

Постановка проблеми. Голштинізована худоба разом з багатьма позитивними ознаками має і низку проблем пов'язаних зі зниженням рівня відтворення, продуктивного довголіття, якості продукції [3, 18]. Одним із методів поліпшення вказаних ознак молочної худоби в товарних стадах є кросбридинг $[4,14]$. Він являє собою систему міжпородного схрещування, за якої у потомства можна очікувати вищі показники окремих кількісних ознак, ніж у батьків за рахунок їхньої гетерозиготності за багатьма генами [5]. У США серед поліпшувальних порід для голштинів найбільш розповсюдженими $\epsilon$ джерсейська, швіцька, айрширська та монбельярдська, а в країнах Свропейського Союзу та Скандинавії також шведська, норвезька та датська червоні породи [5, 10, 11, 17].

Аналіз основних досліджень і публікацій, у яких започатковано розв'язання проблеми. Дослідженнями зарубіжних вчених встановлено, що у кросбредних тварин першого покоління значно поліпшились такі функціональні ознаки, як продуктивне довголіття, якісний склад молока, показники відтворення $[12,13]$. При цьому на
9,4\% зменшились витрати на ветеринарні препарати, тривалість сервіс-періоду скоротилась на 26 днів та на $26 \%$ збільшилась тривалість продуктивного використання $[15,16]$. Тому застосування даного селекційного прийому було б корисним і на вітчизняних комерційних фермах, де використовуються українські молочні породи.

Основними показниками розвитку молодняку за умов різних технологій експлуатації $\epsilon$ інтенсивність їх росту та жива маса за період вирощування [8]. Відомо, що в процесі росту та розвитку тварин інтенсивність обмінних процесів 3 віком зменшується, що зумовлено біологічними особливостями організму [1]. Існують думки, що жива маса не повною мірою відображає інтенсивність росту тварин за віком [9]. Найважливішим показником, за величиною якого можна характеризувати інтенсивність росту тварин, є середньодобовий приріст живої маси.

Мета досліджень полягала в аналізі динаміки живої маси, середньодобових приростів та інтенсивності росту кросбредних телиць порівняно 3 чистопородними аналогами за різних технологій утримання.

Завданням дослідження було вивчити вплив кросбридингу, як елементу поліпшення комерційних стад на показники росту телиць отриманих від вітчизняних порід.

Матеріал і методи досліджень. Дослідження проводили у СТОВ ОП «Михайлівське» с. Михайлівка (49¹1г52ґ пн. ш., 2843г29п сх. д.) Вінницького району Вінницької області на телицях української чорно-рябої молочної породи та помісях першого покоління отриманих в результаті схрещування зі швіцькою породою та у ТОВ «Азорель» с. Мухівці (4857г01п пн. ш., 2847г09п сх. д.) Немирівського району Вінницької області на телицях української червоно-рябої молочної породи та помісях першого покоління отриманих у разі схрещування української червоно-рябої молочної з монбельярдською породою. У СТОВ «Михайлівське» застосовується прив'язно-стійлова система утримання в зимовий та безприв'язна $з$ утриманням на 


\section{СІЛЬСЬКЕ ГОСПОДАРСТВО. ТВАРИННИЦТВО}

вигульно-кормових майданчиках у весняно-осінній періоди. У ТОВ «Азорель» застосовується безприв'язне утримання 3 використанням глибокої довгонезмінюваної підстилки. В обох господарствах було сформовано по дві групи чистопородних та помісних телиць-аналогів 3 чисельністю 25 (СТОВ «Михайлівське») та 20 (ТОВ «Азорель») голів у кожній. В обох господарствах застосовується однотипна цілорічна годівля корів повнораціонними кормосумішами. Дослідження проводили від народження до 18-місячного віку. Упродовж досліджень реєстрували живу масу за народження і щомісячно, середньодобові прирости, індекси що характеризують ріст і розвиток тварин. Спад відносної швидкості росту ремонтних телиць та індекс спаду енергії росту визначали за методикою Ю. К. Свечина та Л. И. Дунаєва [6]. Показники інтенсивності росту тварин - за методиками Ю. К. Свечина [7] та В. П. Коваленко [2].

Результати досліджень. У результаті проведених досліджень встановлено, що у всі вікові періоди вирощування телиці української чорно-рябої молочної породи характеризувалися вищими показниками живої маси порівняно зі швіцькими помісями і у 18-місячному віці різниця становила 14,34 кг, тоді як телиці отримані в результаті схрещування монбельярдської породи з українською червоно-рябою молочною породою навпаки відзначались більшою живою масою порівняно з червоно-рябими анало- гами, а у 18-місячному віці їхня жива маса переважала на 15,23 кг (табл. 1).

Важливим показником, що характеризує ріст телиць, є кратність збільшення їх живої маси (табл. 2). Встановлено, що попри найнижчу живу масу за народження та у всі вікові періоди помісні телиці української чорно-рябої молочної та швіцької порід мали найвищий показник кратності збільшення живої маси - у 12,72 разів (або на 367,24 кг), тоді як у чистопородних аналогів жива маса збільшилась у 12,23 разів (або на 379,16 кг). Помісні телиці монбельярдської та української червоно-рябої молочної серед досліджуваних порід мали найвищу живу масу за народження, але при цьому кратність збільшення їхньої живої маси була найнижчою - у 12,15 разів (або на 406,15 кг). Щодо телиць української червоно-рябої молочної породи, то у них цей показник збільшився у 12,47 разів (або на 398,08 кг). Найвищі середньодобові прирости серед тварин усіх порід були у період від народження до 6-місячного віку (табл. 3). У подальшому, аж до 18-місячного віку цей показник поступово знижувався. Найбільшими середньодобові прирости за весь період вирощування були у помісей української червоно-рябої молочної породи та монбельярдської - 752,19 г, а найменшими у помісей української чорнорябої молочної породи зі швіцами - 681,09 г.

\section{1. Жива маса телиць досліджуваних порід, к2}

\begin{tabular}{|c|c|c|c|c|}
\hline \multirow{2}{*}{ Порода } & \multicolumn{4}{|c|}{ Вікові періоди, місяців } \\
\cline { 2 - 5 } & за народження & 6 & 12 & 18 \\
\hline $\begin{array}{c}\text { Українська чорно-ряба } \\
\text { молочна }\end{array}$ & $33,76 \pm 0,37$ & $198,19 \pm 4,22$ & $307,81 \pm 4,64$ & $412,92 \pm 5,08$ \\
\hline $\begin{array}{c}\text { Помісі української чорно- } \\
\text { рябої молочної та швіцької }\end{array}$ & $31,34 \pm 0,72^{* *}$ & $186,49 \pm 3,71^{*}$ & $296,38 \pm 4,52$ & $398,58 \pm 5,74$ \\
\hline $\begin{array}{c}\text { Українська червоно-ряба } \\
\text { молочна }\end{array}$ & $34,26 \pm 0,53$ & $204,27 \pm 4,86$ & $316,51 \pm 5,27$ & $427,34 \pm 4,86$ \\
\hline $\begin{array}{c}\text { Помісі української черво- } \\
\text { но-рябої молочної та } \\
\text { монбельярдської }\end{array}$ & $36,42 \pm 0,37^{* *}$ & $212,31 \pm 3,58$ & $328,16 \pm 4,73$ & $442,57 \pm 5,19^{*}$ \\
\hline
\end{tabular}

Примітка: *-P<0,05; **_- $<0,01$ порівняно з украӥнськими чорно- та червоно-рябими молочними породами.

\section{2. Кратність збільщення жнивӧ маси телиць, разів}

\begin{tabular}{|c|c|c|c|}
\hline \multirow{2}{*}{ Порода } & \multicolumn{3}{|c|}{ Вікові періоди, місяців } \\
\cline { 2 - 4 } & 6 & 12 & 18 \\
\hline Українська чорно-ряба молочна & $5,88 \pm 0,02$ & $9,69 \pm 0,03$ & $12,97 \pm 0,05$ \\
\hline $\begin{array}{c}\text { Помісі української чорно-рябої мо- } \\
\text { лочної та швіцької }\end{array}$ & $5,94 \pm 0,02 *$ & $9,45 \pm 0,02 * * *$ & $12,71 \pm 0,04 * * *$ \\
\hline Українська червоно-ряба молочна & $5,95 \pm 0,03$ & $9,23 \pm 0,06$ & $12,47 \pm 0,04$ \\
\hline $\begin{array}{c}\text { Помісі української червоно-рябої } \\
\text { молочної та монбельярдської }\end{array}$ & $5,82 \pm 0,02 * * *$ & $9,01 \pm 0,07 *$ & $12,15 \pm 0,05 * * *$ \\
\hline
\end{tabular}

Примітка: *-P<0,05; ***-P<0,001 порівняно з українськими чорно- па червоно-рябими молочними породами. 
СІЛЬСЬКЕ ГОСПОДАРСТВО. ТВАРИННИЦТВО

\section{3. Середньодобові прирости телиць у період вирощування, 2}

\begin{tabular}{|c|c|c|c|c|}
\hline \multirow{2}{*}{ Порода } & \multicolumn{4}{|c|}{ Вікові періоди, місяців } \\
\cline { 2 - 5 } & $0-6$ & $6-12$ & $12-18$ & $0-18$ \\
\hline $\begin{array}{c}\text { Українська чорно-ряба } \\
\text { молочна }\end{array}$ & $913,22 \pm 2,14$ & $607,54 \pm 1,73$ & $581,94 \pm 2,03$ & $702,37 \pm 1,74$ \\
\hline $\begin{array}{c}\text { Помісі української чорно- } \\
\text { рябої молочної та } \\
\text { швіцької }\end{array}$ & $861,95 \pm 1,72 * * *$ & $610,57 \pm 1,58$ & $570,35 \pm 1,84 * * *$ & $681,09 \pm 2,06 * * *$ \\
\hline $\begin{array}{c}\text { Українська червоно-ряба } \\
\text { молочна }\end{array}$ & $944,47 \pm 2,83$ & $622,84 \pm 1,84$ & $615,26 \pm 2,31$ & $727,90 \pm 2,26$ \\
\hline $\begin{array}{c}\text { Помісі української } \\
\text { червоно-рябої молочної } \\
\text { та монбельярдської }\end{array}$ & $977,08 \pm 2,26^{* * *}$ & $642,74 \pm 2,09 * * *$ & $634,08 \pm 2,12 * * *$ & $752,19 \pm 3,32^{* * *}$ \\
\hline
\end{tabular}

Примітка: ***_- $<0,001$ порівняно з українськими чорно- та червоно-рябими молочними породами.

4. Відносна ивидкість росту телиць, \%

\begin{tabular}{|c|c|c|c|c|}
\hline \multirow{2}{*}{ Порода } & \multicolumn{4}{|c|}{ Вікові періоди, місяців } \\
\cline { 2 - 5 } & $0-6$ & $6-12$ & $12-18$ & $0-18$ \\
\hline Українська чорно-ряба молочна & $141,77 \pm 0,26$ & $43,30 \pm 0,19$ & $29,17 \pm 0,18$ & $169,76 \pm 0,14$ \\
\hline $\begin{array}{c}\text { Помісі української чорно-рябої } \\
\text { молочної та швіцької }\end{array}$ & $142,44 \pm 0,20^{*}$ & $48,07 \pm 0,16^{* * *}$ & $29,38 \pm 0,17$ & $171,04 \pm 0,16^{* * *}$ \\
\hline Українська червоно-ряба молочна & $142,53 \pm 0,34$ & $43,12 \pm 0,20$ & $30,01 \pm 0,19$ & $170,31 \pm 0,20$ \\
\hline $\begin{array}{c}\text { Помісі української червоно-рябої } \\
\text { молочної та монбельярдської }\end{array}$ & $141,43 \pm 0,28^{*}$ & $42,87 \pm 0,28$ & $29,46 \pm 0,26$ & $169,52 \pm 0,33$ \\
\hline
\end{tabular}

Примітка: *-P<0,05; ***-P<0,001 порівняно з украӥнською чорно-рябою молочною породою.

5. Індекси, щңо характеризують ріст телиць

\begin{tabular}{|c|c|c|c|c|c|c|}
\hline Порода & 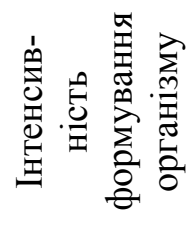 & 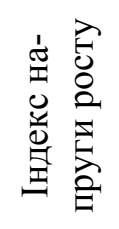 & 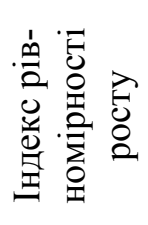 & 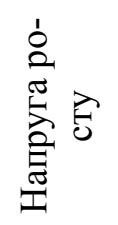 & 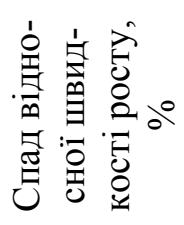 & 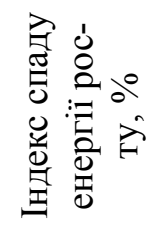 \\
\hline Українська чорно-ряба молочна & 0,980 & 0,090 & 0,378 & 1,485 & $\begin{array}{c}99,21 \pm \\
1,64\end{array}$ & $\begin{array}{c}112,58 \pm \\
0,86\end{array}$ \\
\hline $\begin{array}{r}\text { Помісі української чс } \\
\text { молочної та шві }\end{array}$ & 0,933 & 0,079 & 0,376 & 1,401 & $\begin{array}{l}92,34 \pm \\
1,56 * *\end{array}$ & $\begin{array}{c}111,70 \pm \\
0,42\end{array}$ \\
\hline Українська червоно-ряба молочна & 0,991 & 0,092 & 0,388 & 1,538 & $\begin{array}{c}101,12 \pm \\
1,32\end{array}$ & $\begin{array}{c}112,72 \pm \\
0,73\end{array}$ \\
\hline \begin{tabular}{|c} 
Помісі української червоно-рябої \\
молочної та монбельярдської
\end{tabular} & 0,995 & 0,099 & 0,401 & 1,594 & $\begin{array}{c}102,37 \pm \\
1,58\end{array}$ & $\begin{array}{c}111,84 \pm \\
0,93\end{array}$ \\
\hline
\end{tabular}

Примітка: ** - $<<0,01$ порівняно з украӥнською чорно-рябою молочною породою.

Найвища відносна швидкість росту живої маси в усіх групах піддослідних тварин спостерігалася у період від народження до 6 місяців $141,43-142,53 \%$ (табл. 4). 3 віком теличок цей показник зменшувався, і найнижчим він був у період від 12- до 18-місячного віку 29,17$30,01 \%$.

3 метою оцінки закономірностей росту телиць нами вивчено індекси, що характеризують інтенсивність їх росту (табл. 5). Встановлено, що телиці української чорно-рябої молочної породи мали більш високі показники за всіма індексами порівняно $з$ телицями швіцьких помісей. Зокрема за індексом інтенсивності спаду росту вони переважали помісних тварин на 0,88 \%, що вказує на дещо вищу інтенсивність формування в ранньому онтогенезі. В іншому досліді показники характеру росту телиць помісей української червоно-рябої молочної породи та монбельярдської переважали червоно-рябих аналогів за всіма показниками, крім індексу спаду енергії росту $(<$ на $2,60 \%)$. 


\section{Висновки:}

1. Встановлено, що використання кросбридингу, як елемента поліпшення комерційних стад по-різному вплинуло на ріст і розвиток телиць першого покоління у порівнянні $з$ чистопородними аналогами. Чистопородні телиці української чорно-рябої молочної породи характеризувалися більш високими показниками живої маси порівняно зі швіцькими помісями, тоді як телиці, отримані в результаті схрещування монбельярдів

\section{БІБЛІОГРАФІЯ}

1. Гавриленко М. С. Ріст телиць голштинської породи залежно від їхньої лінійної належності / М. С. Гавриленко, Н. В. Куновська // Розведення і генетика тварин : між від. темат. наук. зб. 2005. - Вип. 38. - С. 136-138.

2. Коваленко В. П. Молочна продуктивність корів у залежності від інтенсивності їх росту / В. П. Коваленко // Науково-технічний бюлетень. - Х., 2001. - №30. - C. 71-73.

3. Кросбридинг як елемент високопродуктивного молочного скотарства / [Рубан С. Ю., Федота О. М., Мітіогло В. О. та ін.] // Біологія тварин, 2016. - Т. 18, №2. - С. 94-104.

4. Сучасні технології виробництва молока (особливості експлуатації, технологічні рішення, ескізні проекти) / [Рубан С. Ю., Борщ О. В., Борщ О. О. та ін.]. - Х. : ФОП О. В. Бровін, 2017. $-172 \mathrm{c}$.

5. Світовий досвід та перспективи використання геномної селекції в молочному скотарстві / [Рубан С. Ю., Даншин В. О., Федота О. М. та ін.] // Біологія тварин, 2016. - Т. 18. - №1. C. 117-125.

6. Свечин Ю. К. Прогнозирование молочной продуктивности крупного рогатого скота / Ю. К. Свечин, Л. И. Дунаев // Зоотехния. - 1989. - №1. - C. 49-53.

7. Свечин Ю. К. Прогнозирование продуктивности в раннем возрасте / К. Б. Свечин // Вестник с.-х. науки. - 1985. - №4. - С. 103-108.

8. Федорович $€$. Західний внутрішньопородний тип української чорно-рябої молочної породи / Є. Федорович // Тваринництво України. 2009. - №4. - C. 22-23.

9. Федорович $C$. I. Західний внутрішньопородний тип української чорно-рябої молочної породи: Господарсько-біологічні та селекційногенетичні особливості / Є. І. Федорович, Й. 3. Сірацький. - К. : Науковий світ, 2004. - 385 с.

10. Milk, Fat, Protein, Somatic Cell Score, and Days Open Among Holstein, Brown Swiss, and Their Crosses / [Dechow C. D., Rogers G. W., Cooper J. B. et al.] // Journal of Dairy Science. -
3 українською червоно-рябою молочною, навпаки відзначались більшою живою масою порівняно $з$ чистопородними червоно-рябими аналогами.

2. Найвищі середньодобові прирости та відповідно і відносна швидкість росту у період від народження до 6-, 12- та 18-місячного віку були у телиць помісей української червоно-рябої молочної з монбельярдською породою.

2007. - Vol. 90. - PP. 3542-3549.

11. Dezetter $C$. Inbreding and Crossbreeding parameters for production and fertility traits in Holstein, Montbeliearde and Normande cows / [Dezetter C., Leclerc H., Mattalia S. et al.] // Journal of Dairy Science. -2015. -Vol. 98. - PP. 4904-4913.

12. Ferris C.P. An examination of the potential of crossbreeding to improve the profitability of dairying in Northern Ireland. Final Report for AgriSearch. - 2012. - P. 24.

13. Ferris C. P. Crossbreeding in Dairy Cattle: Pros and Cons / C. P. Ferri, B. J. Heins, F. Buckley // WCDS Advances in Dairy Technology. - 2014. Vol. 26. - PP. 223-243.

14. Heins B. Y. Production of pure Holsteins versus crossbreds of Holstein with Normande, Montbeliearde, and Scandinavi on Red / B. Y. Heins, L. B. Hansen, A. Y. Seykora // Journal of Dairy Science. - 2006. - Vol. 89. - PP. 2799-2804.

15. Heins B.J. Short communication: Fertility, somatic cell score, and production of Normande $\mathrm{Y}$ Holstein, Montbŭliarde Ч Holstein, and Scandinavian Red Ч Holstein crossbreds versus pure Holsteins during their first 5 lactations / B. J. Heins, L. B. Hansen // Journal of Dairy Science. - 2012. Vol. - 95. - PP. 918-924.

16. Heins B. J. Survival, lifetime production, and profitability of crossbreds of Holstein with Normande, Montbŭliarde, and Scandinavian Red compared to pure Holstein cows / B. J. Heins, L. B. Hansen, A. De Vries // Journal of Dairy Science. 2012. - Vol. - 95. - PP. 1011-1021.

17. Petersen W. E. Crossbreeding of Dairy Cattle: The Science and the Impact Presented by the Department of Animal Science University of Minnesota, St. Paul April 2, 2007. - P. 21.

18. Weigel K. A. Crossbreeding: a dirty word or an opportunity? Retrieved October 5, 2010, from American Jersey Cattle Association [Електронний peсурс]. - - Режим доступу www.usjersey.com/Reference/ WeigelCrossbreeding\%2007WDMC.pdf. 